International Journal of Environment, Agriculture and Biotechnology
Vol-6, Issue-1; Jan-Feb, 2021
Journal Home Page Available: https://ijeab.com/
Journal DOI: $10.22161 /$ ijeab

\title{
Contribution of traditional Date palm (Phoenix sylvestris) agroforestry in income generation and livelihood improvements: A case of Jashore district, Bangladesh
}

\author{
M.A. Mondol ${ }^{1 *}$, N. E. K. Alam² and K. K. Islam ${ }^{2}$ \\ ${ }^{1,2}$ Department of Agroforestry, Bangladesh Agricultural University, Mymensingh-2202, Bangladesh. \\ ${ }^{1}$ Bangladesh Sugar and Food Industries Corporation, Bangladesh \\ *Corresponding Author
}

Received: 13 Oct 2020; Received in revised form: 21 Jan 2021; Accepted: 16 Feb 2021; Available online: 28 Feb 2021 (C)2021 The Author(s). Published by Infogain Publication. This is an open access article under the CC BY license (https://creativecommons.org/licenses/by/4.0/).

\begin{abstract}
Products and services provided by the agroforestry production systems support the basic needs and enhance the livelihood of millions of farmers throughout the world. The benefit of the traditional agroforestry systems and their livelihood improvement strategies are, however, often not systematically addresses in Bangladesh. Thus, the objective of the study was to assess the impact of traditional agroforestry on income generation and livelihood capital development of the rural farmers in Bangladesh. The study selected one of the most common and popular Date palms (Phoenix sylvestris) agroforestry cases practiced in the Jashore region of Bangladesh. The findings indicated that the most common important feature of the Date palm-based agroforestry system was to generate income and diversified products for the rural farmers. In addition, the physical, financial and natural capital developments were a strong indication of the livelihood developments of farmers. However, the social and human capital development was not satisfactory and this urges an immediate intervention from the government and regional levels. The scientific training on agroforestry and local conflict resolution mechanism process from the government levels would be boosted up the income generation and livelihood development of the farmers in the study area. Therefore, the study recommends to minimize constraints of the agroforestry production systems through training and also enhance social relationship through government official interference would be very effective to make the Date palm agroforestry a more sustainable land-use practice in Bangladesh.
\end{abstract}

Keywords-Agroforestry, Date palm, Benefit-Cost, Livelihood capitals, Bangladesh.

\section{INTRODUCTION}

With rapid population growth and a significant increase in wealth, put pressure to convert natural forests into commercial agriculture, industrial and infrastructure used in the world. This pressure also increases the demand for food, timber, fuel, fodder, fiber and other tree products, and also puts additional pressure on the existing forests. On the contrary, these forest ecosystems are expected to provide a diverse array of environmental services (Roshetko, 2013). Agroforestry practice can be a solution to the rising population of the developing world as it helps to utilize every piece of land sustainably. Agroforestry systems that rural people have developed with limited resources (e.g., land) to meet their household needs are a key opening to advance the sustainable use of forest products and services. Agroforestry is an integral part of the rural livelihood systems for centuries and plays a key role in providing household food and energy security, income and employment generation, investment opportunities and environmental protection in Bangladesh (Miah et al, 2002).

In Bangladesh, the rural farmers adopted a number of traditional agroforestry systems on their farm and sustain their livelihood since time immemorial. Wild Date palm 
(Phoenix sylvestris) based traditional agroforestry is one of the common and popular systems practiced in the greater Jashore region of Bangladesh (Abedin et al, 1997). Alone with Date palm there are only a few traditional agroforestry systems are practiced in different agroecological zones in Bangladesh, and due to variation in soil, climate and rainfall these traditional agroforestry systems are found in specific locations mainly. The farmers manage the Date palm tree mainly for sap production with which sugar-based secondary goods are manufactured. The sap is either used fresh as a drink or after some sort of processing as molasses (Chowdhury et $a l, 2008)$. In Jashore area, farmers are cultivating different vegetables and cereal crops in association with Date palm trees and sustain their livelihood with higher farm outputs (Islam et al, 2013; Islam, 2019). The Date palm tree required minimum management effort and farmers get tapped juice from the tree every year and the production cycle runs for more than 20 years.

The Date palm-based agroforestry systems have the capacity to enhanced farmers' income which has already been documented by the researchers (Miah et al, 2002; Hajonget al, 2016). However, the livelihood improvement of the traditional agroforestry and its contribution to different asset development of the rural farmers have not been addressed thoroughly. Only some previous study has sporadically calculated income generation of the Date palm trees in Bangladesh and as a traditional agroforestry system, the productivity of the system has not assessed properly. Therefore, the objectives of the study were to assess the impacts of Date palm-based agroforestry systems on the income generation and livelihood improvements of rural farmers of Jashore region of Bangladesh.

Conceptual and Theoretical frameworks: Most of the livelihood concepts have a focus on the household as the most appropriate social group for the investigation of livelihood. Several agencies (e.g., CARE, UNDP, FAO) have adopted livelihood approaches and make use of livelihood frameworks. This study used the DFID Sustainable Livelihood framework as a point of reference. The DFID's sustainable livelihood framework looks at the basic dynamics of livelihoods and how people are represented on a set of capital/assets as a basis for their livelihoods (Carney, 1998; Hussein and Nelson, 1998). In the DFID's sustainable livelihood framework these assets are represented by - Human capital (skill, knowledge, capacity, labor ability, good health), Social capital (relationship of trust and reciprocity, networks, membership of groups), Physical capital (basic infrastructure, transport, shelter, communications), Natural capital (land, forest, water, wildlife, biodiversity) and
Financial capital (monetary resources-savings, credit, remittances).

The traditional agroforestry systems in Bangladesh have been contributing to the livelihoods of the rural farmers mainly by contributing to the development of livelihood assets/capital. The assets are the livelihood building blocks and a range of assets are needed to attain positive livelihood outcomes (Islam and Sato, 2012a\&2013; Warner, 2003). Improvement in all the five capitals could be termed as strong improvement, while improvement in only some of the capitals that compensate for any decline in other capitals could be termed as weak or poor improvement of livelihoods (Das, 2009). This study analyses the base assets of the participants and explores their access to livelihood assets in the context of the traditional agroforestry systems (Shahabaz, 2009). So, the livelihoods of the rural farmers have been evaluated in this study with the help of DFID's livelihood framework.

\section{METHODOLOGY}

\section{Description of the Date Palm agroforestry systems}

The Date palm-based traditional agroforestry systems are very popular and common practices in the greater Jashore region of Bangladesh. The Date palm tree is an evergreen and commercial species that has been practicing in this region since time immemorial (Abedin and Quddus, 1990; Hajonget al, 2016). Usually, the Date palm trees are growing in the boundary or inside the cropland in a scattered manner (Figure 2), and different crops are grown in association with the trees. As a deep-rooted and straight canopy bearing tree species, the Date palm has occurred minimum competition with associated crops in terms of water, light and nutrients (Nair and Graetz, 2004; Nair and Latt, 1997). The Date palm tree provided juices in the winter season and the juice is used to make molasses (locally called Khejurgur). Molasses is an important source of sugar and a good substitute for sugarcane sugar in Bangladesh. The farmers sell juice and sugar to the market and also collected firewood, timber and fruits periodically from the Date palm trees. The Date palm is easily germinated through seeds and established in the soil even in poor-quality soil. The soil (sandy loam) and climate (moderately higher temperature) of the greater Jashore region are favorable for growing Date palm tree (Hajonget al, 2016; Dalibard, 2007). The study observed that rural farmers were cultivated different winter vegetables (e.g., cabbage, cauliflower, radish, turnip, green pea, carrot, Indian spinach, etc.) and cereal crops like rice and mustard in association with Date palm trees in the Jashore district of Bangladesh. The Date palm-based agroforestry systems could be continuing up to 30 years 
and the young tree produce juice after 5-years of tree plantation.

Study Location: The study was conducted in Barinagar, Panchbaria and Khajura, 3 villages under the Jashore district of Bangladesh. The villages were belonging to the
High Ganges River Floodplain Agroecological zones (Figure 1) and the soil of the Jashore region is calcareous dark grey to the brown floodplain and the average rainfall is $1640 \mathrm{~mm}$ per annum.

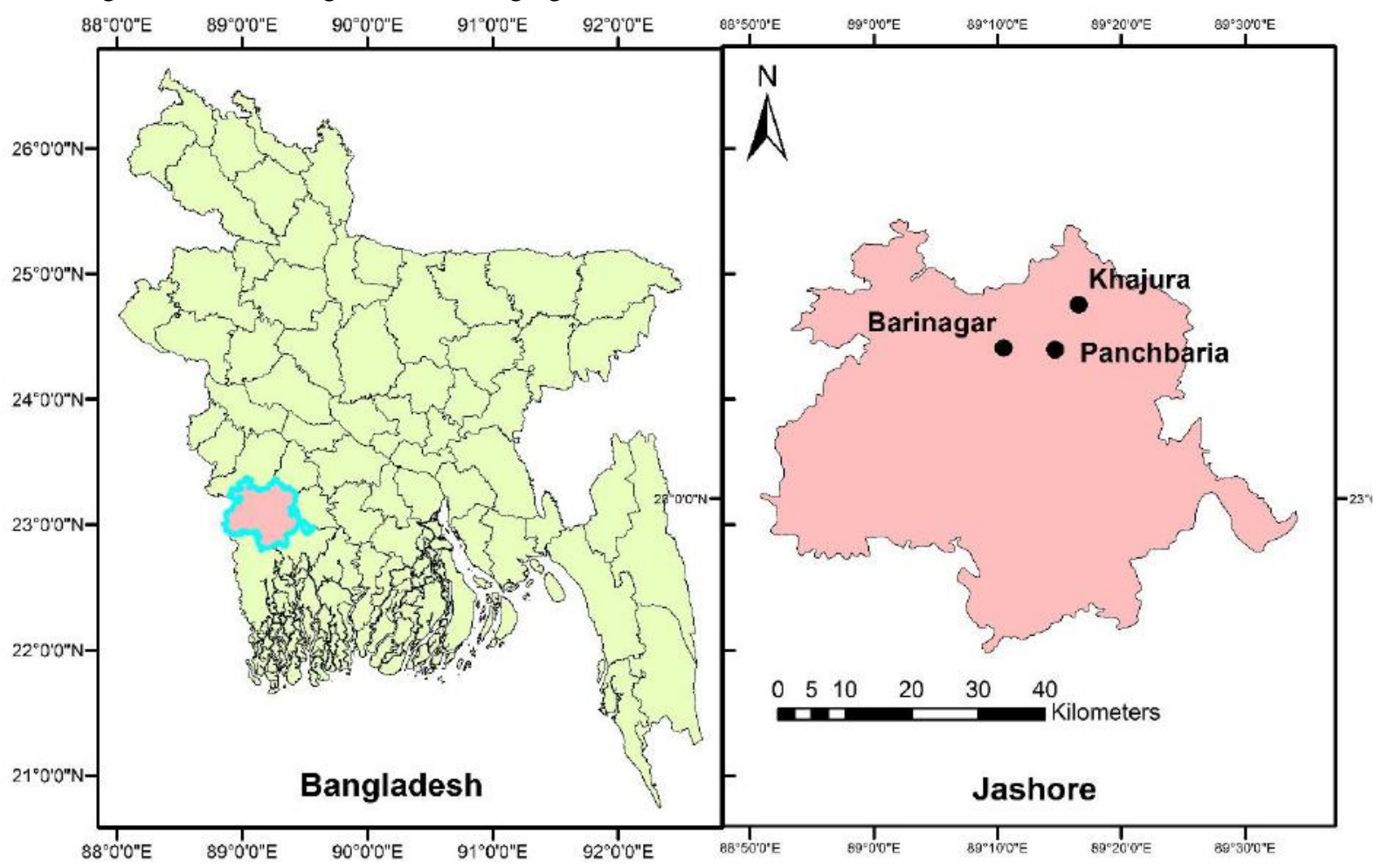

Fig. 1: Study area map showing Bangladesh (left) and Jashore (right) district

The soil and climate of the Jashore region are good for vegetable cultivation as the soil is predominantly sandy loam. The farmers grow different winter and summer vegetables like (Cabbage, cauliflower, radish, etc.) and cereal and pulse crops (rice, pulses) in association with Date palm trees.

\section{Sampling and Data Collection}

Prior to data collection, the study was collected traditional agroforestry farmers' information with an informal discussion with the local people of the communities and from the respective agricultural offices. A pilot survey of 5 farmers was conducted in the Jashore region and then the interview questionnaire was adjusted and finalize for data collection. The primary data of this study was collected through household interviews and focus group discussions. For the farmers' household survey, the study selected 60 farmers randomly from the three villages, where 20 farmers represent from each village. The selected farmers were practiced traditional agroforestry on their own farms for more than 5 years. The interview was carried out with the help of a semi-structured questionnaire, the questionnaire consists of farmers socioeconomic information, their agroforestry income, improvement of five livelihood capitals through agroforestry systems and the problems faced by the farmers in the community. Interviews were held in the day time with the help of two enumerators and in the native Bengali language. In addition to the household interview, the study also conducted focus group discussions and in each of the villages we took two focus group discussions. The farmers were informed about the focus group discussion and their perceptions were recorded accordingly. Repeated conservation with farmers was made in each common and decision-making question to ensure the validity of the information. Finally, the collected data were verified, cross-checked and validated in the study, the whole data collection period was conducted between 2019 and 2020 time period.

\section{Data analysis}

The Date palm-based agroforestry provided diversified outputs from crops and tree products. Crops were cultivated at a different time of the whole year and Date palm tree provided Juice during the winter season of (Late November to February) Bangladesh. The study collected 
all crops yield grown in association with Date palm tree and converted it to hectare basis. Like crop yield, all firewood, fruits, juice, molasses and other non-timber products income were calculated on the year per hectare basis. Finally, all of the products' income were calculated with their prevailing average market price in Bangladesh Taka ( 1 USD $\approx 84$ Taka). The study also calculated the Benefit-Cost Ratio (BCR) of the Date palm-based traditional agroforestry system, which indicates the rate of return per unit cost, was calculated using the following formula, $\mathrm{BCR}=\frac{\sum_{t=0}^{n} \frac{B_{t}}{(1+r)}}{\sum_{t=0}^{n} \frac{C_{t}}{(1+r)}}$ here, $\mathrm{B}_{\mathrm{t}}=$ gross benefit in $\mathrm{i}^{\text {th }}$ year, $\mathrm{C}_{\mathrm{t}}=$ total cost in $\mathrm{i}^{\text {th }}$ year, $\mathrm{t}=$ number of year and $\mathrm{i}=$ interest (discount) rate (assuming 11\% interest rate). Finally, the procured data were tabulated and analyzed using Microsoft Excel.

\section{RESULTS AND DISCUSSIONS}

\section{Demographic Characteristics of the Farmers}

The study found that the variation of farmer households' size among the three villages was very insignificant and their average size was more than 6 (Table 1). The mean ages of the participants were 46 years (Table 1 ). The male and female ratio among the participant households was almost the same among the three villages. In the case of the literacy rate, the farmers from Khajura possess a slightly higher $(60 \%)$ rate (Table 1$)$ than the literacy rate of the overall civil district (Jashore) $56.5 \%$ (BBS, 2013). The majority of participants' religion was Islam and the rest was Hinduism. The average landholding of households was 0.63 ha (Table 1) and the households' main sources of income are dominantly agriculture (Table 1).

Table 1: Demographic features of the respondent

\begin{tabular}{lcrr}
\hline Characteristics & Khajura & Barinagar & Panchbaria \\
\hline Age (Mean) & 46.8 & 43.65 & 48.2 \\
Household size (Mean) & 6.6 & 6.1 & 6.35 \\
Male: Female ratio & $49: 51$ & $50: 50$ & $49: 51$ \\
Literacy rate & $60 \%$ & $45 \%$ & $55 \%$ \\
Per household landholding (ha) (Mean) & 0.72 & 0.56 & 0.60 \\
Distribution of households by religion & & & $85 \%$ \\
- Muslim & $90 \%$ & $85 \%$ & $15 \%$ \\
- Hindu & $10 \%$ & $15 \%$ & $0 \%$ \\
- Others & $0 \%$ & $0 \%$ & $70 \%$ \\
Households main sources of income & & & $15 \%$ \\
- Agriculture & & $65 \%$ & $10 \%$ \\
- Wage labor & $60 \%$ & $15 \%$ & $5 \%$ \\
- Business & $20 \%$ & $15 \%$ & $0 \%$ \\
- Unemployment & $10 \%$ & $5 \%$ & $0 \%$ \\
- Remittances & $0 \%$ & $0 \%$ & \\
- Others & $5 \%$ & $5 \%$ & \\
\hline
\end{tabular}

\section{Economic Return from Date Palm Agroforestry}

Economic outcomes from the tree-crop based agroforestry systems play a key role in the household income in rural farmers of Bangladesh. The traditional agroforestry system based on date palm was executed to improve the livelihood of the local community. The economic analysis showed that the outputs of traditional agroforestry mainly depend on the crops' income (Table 2). The Date palm traditional agroforestry needs an intensive labor cost that was considered the main costs of the production systems. However, the date palm tree can regenerate easily through seeds and farmers did not need to pay a higher amount of money to buy and establish the Date palm tree in their farms. The whole production costs and the average yield of the production systems are presented in Table 2. 
Table 2: Economic returns from the Date Palm based agroforestry practices

\begin{tabular}{|c|c|}
\hline Items & Different cost/income \\
\hline Tree establishment and new seedlings costs & 5917 \\
\hline Land preparation costs & 12900 \\
\hline Vegetables cultivation costs & 29250 \\
\hline Seasonal crops cultivation costs & 15217 \\
\hline Labor costs & 33000 \\
\hline Fertilizers costs & 8075 \\
\hline Manure costs & 6200 \\
\hline Insecticides and pesticides costs & 5883 \\
\hline Weeding and irrigation costs & 6825 \\
\hline Harvesting of crops and vegetables costs & 14167 \\
\hline Other management costs & 5750 \\
\hline Income from date timber* & 29333 \\
\hline Income from date palm juice & 12733 \\
\hline Income from date palm molasses/Ghur & 43583 \\
\hline Thinning tree and firewood income & 13308 \\
\hline Fodder income & 6200 \\
\hline Vegetables income & 125167 \\
\hline Other seasonal crops income & 71167 \\
\hline Total Gross Income & 301492 \\
\hline Total Production Cost & 143183 \\
\hline Net Income & 158308 \\
\hline Benefit Cost Ratio (BCR) & 2.11 \\
\hline
\end{tabular}

It was evident that the farmers were cultivated different vegetables and cereal crops in association with Date palm trees and earned a significant income (126267 and 71167 Taka) respectively (Table 2). Date palm tree provided fresh juice in the winter season and farmers reported that they tapped tree twice a week and, on average, they collected 4-liter juice from one tree per tap. On average, they collected more than 120 liters of juice from a tree in the whole winter season. The farmers produced molasses from the juice in simple burning/heating techniques, and on average 100-liter juice produce $16 \mathrm{~kg}$ molasses locally. The local price of $1 \mathrm{~kg}$ molasses (Ghur) has more than 170 Taka and the farmers can profit more than 2200 Taka from the molasses per Date palm tree in a year. Therefore, the income from molasses was an additional income from the agroforestry farmers. In addition to the timber, firewood and juice income, the date tree leaves are used to produce some local mat and sold in the local market. The benefitcost ratio (BCR) is a common indicator of economic analysis as it takes into account both costs and returns of both components. The BCR value of the date palm-based agroforestry showed 2.11 which is quite satisfactory in respect of the regions.

The study pointed out that the resilience of agroforestry farmers was strengthened through the locally adopted Date palm species in their agricultural lands which provide farmers a valuable source of income. The production systems outputs like timber, firewood, juice, molasses and other non-timber products were the backup against income risks in case of crop failure (Avelino et al, 2011; Brancaet $a l, 2011)$. The outcomes of the agroforestry systems also revealed that the farmers get a continuous source of income throughout the year and the benefit-cost ratio of the systems was much higher than the general agriculture practices of the country (Islam, 2019).

\section{Livelihood Improvements}

The rural poor farmers have practiced Date palm-based traditional agroforestry system in order to support their daily living. After involvement in the program, they were 
able to build up several types of livelihood capitals and this study examines some important variables of these capitals (DFID, 2001; Islam et al, 2012a\&2012b).

A few training sessions and workshops (28\%) were conducted by the local NGOs and GOs in order to familiarize the scientific training on agroforestry (Table 2). But it is not enough to train farmers in an effective fashion as the Date palm-based agroforestry would require specific knowledge to manage the systems scientifically. Most of the farmers were thus used traditional knowledge to manage their production systems which they learned from their parents and grandparents. The literacy rate among farmers appeared to be improved slowly (53.5\%) among the participants (Table 2). The available labor of the participants' families had decreased and it occurred due to the consciousness of education and migration to the capital city and suburbs for better livelihood, mentioned by the respondents. Food sufficiency of the household members throughout the year was found to be quite positive and improving after involving in the traditional agroforestry system. Nevertheless, poor populations living in rural areas normally have limited access to health services. In Bangladesh, the government health program tends to have better coverage in urban areas (Islam et al, 2013). The participants were found to be capable to manage their family healthcare systems and visited the local clinic/hospital for the treatments. The income from the agroforestry systems was able to accommodate the farmers to visits the private clinic or local hospital, mentioned by the participants. So, the human capital of the farmers' waw improved but not at a good level, three is ample of scope to improve further.

There is much debate about what is exactly meant by the term 'social capital' (DFID, 2001). Social capital refers to a network of mutual support that exists within and between households, extended family and communities, which people can utilize to gain, for example, loans, child care, food, accommodation and information about employment and opportunities (Dersham and Gzirishvili, 1998; Moser, 1998). In addition, social capital is a valuable and critical resource for poor people, especially during times of crisis and socioeconomic change (Islam et al, 2013). The study found out that the agroforestry farmers were able to build a strong relationship with other agroforestry farmers in the community, however, their social relationship with the elite and leaders of the community was negative. In addition, the farmers' relationship with agriculture officers were moderate. Date palm farmers have developed the social relationship and trust in themselves, however, the traditional agroforestry systems have a long history and acceptable production systems in the Jashore region, Bangladesh. Although social relationship and networks are attributes of an individual in a social context (Sobel, 2002), the establishment of social assets depends on the institution, attitudes and values that govern interactions among participants and contribute to economic and social development (World Bank, 2002), and the overall social assets of the agroforestry farmers have been in improving trends (Table 2).

Natural capital is the term used for the natural stocks from which resources flow and from which services, useful for livelihoods, are derived (DFID, 2001). It refers to environmental assets such as land and common property resources or free (open access) natural resources such as forests, water, or grazing land (Islam et al, 2013). The land is an important natural capital and the respondents were categorized as either landless (having 0 to 0.2 ha land), marginal (0.2 to $0.6 \mathrm{ha}$ ), small (0.61 to $1.0 \mathrm{ha}$ ), medium (1.0 to $2.0 \mathrm{ha}$ ) or large (>2.0 ha) farmers according to their farmland area (Iqbal 2007). The participants were small farmers as they had less (0.62 ha) household land (Table 2 ). The study found out the farmers' perceptions towards conserving the Date palm trees were very positive and every farmer has maintained a good (around 90 trees per ha) number of trees in their farmland. In addition, farmers' awareness to preserve and maintain green cover in their homestead area was also high and they planted fruit trees in their homestead. On average each farmer has 17 tree species in their homestead, which provide diversified foods and nutritional sources for their family members. Therefore, the development of their natural capital was improving and the traditional agroforestry systems tents to improve the situation gradually.

Table 2. State of major characteristics of the participants in the community.

\begin{tabular}{lll}
\hline Parameters & Status & Trends \\
\hline Farmers Literacy rate & $53.5 \%$ & Improving slowly \\
Children literacy rate & $82 \%$ & Sharply improving \\
Involvement in social organizations & $>9$ & Increasing \\
NGOs and GOs & $>21$ & Increasing \\
Micro-credit and easy loan facilities & Good & Increase Microcredit/easy \\
\hline
\end{tabular}




\begin{tabular}{|c|c|c|}
\hline & & loan \\
\hline $\begin{array}{l}\text { Farmers received scientific training on } \\
\text { agroforestry }\end{array}$ & $28 \%$ & Not satisfactory \\
\hline $\begin{array}{l}\text { Farmers social relationship with other } \\
\text { stakeholders of the community }\end{array}$ & Moderate & Gradually improving \\
\hline Household infrastructure and physical assets & $\begin{array}{l}\text { Tin-wall and Roof, shift } \\
\text { from mud-wall and sun-grass } \\
\text { roof }\end{array}$ & Increasing physical assets \\
\hline Road infrastructure to farm and markets & Brick and bitumen seal & Improving \\
\hline Livestock small (e.g., chicken) & 3.8 & Increasing \\
\hline Livestock big (e.g., cow, goat) & 3.2 & Slightly improving \\
\hline Available of labor in the households & 1.6 & Slightly decreasing \\
\hline $\begin{array}{l}\text { Alternative market facilities to sell agroforestry } \\
\text { products }\end{array}$ & Two & Not changing \\
\hline $\begin{array}{l}\text { Food sufficiency of the household members } \\
\text { throughout the year }\end{array}$ & 11 months & Increasing \\
\hline Annual expenditure & $94.5 \%$ & Slightly improving \\
\hline Local Clinic and Hospital facilities for farmers & 2.0 & $\begin{array}{l}\text { not changing but small clinic } \\
\text { increasing in the village } \\
\text { market area }\end{array}$ \\
\hline Tree stock in household premises & 16.5 & Improving \\
\hline Tree stock in AF system & 90 & Not changing \\
\hline Alternative livelihood options & Exist & Increasing \\
\hline
\end{tabular}

Physical capital is comprised of the basic infrastructure and producer goods needed to support livelihoods. It includes assets such as housing, the tools and equipment that people own, rent, or use and the public infrastructure that they have access to (DFID, 2001). Housing is normally one of the most important assets for poor rural households as it is used both for shelter and reproductive purposes and for productive or income-generating purposes (renting out of rooms or using the space as a workshop area) (Moser, 1998). Nowadays, houses made using brick walls and tin roofs represent the standard house structure in the rural areas of Bangladesh (Islam et al, 2013). The majority (>80\%) of the participants' houses were made of mud-walls with sun-grass roofs but some participants (about 20\%) did have tin-wall and tin-roofed houses. On the contrary, local road infrastructure was gradually improved and mud-roads had been replaced by brick and bitumen sealed roads (Table 2). Participants were able to buy small and big livestock with the money they earned from the date-palm based traditional agroforestry program. Moreover, few respondents stated that they bought smartphones and television with the profit from the traditional agroforestry system. Farmers received a good amount of money after selling molasses in the winter seasons and able to buy some small and big livestock and often repaired their house structure. Therefore, the development of the physical asset of the traditional agroforestry farmers was a good sign to improve their livelihood.

Financial capital denotes the financial resources that participants use to achieve their livelihood objectives (DFID, 2001). Income from the sale of labor was often one of the most important assets for the rural farmers. There are two main sources of financial capital: available stock (e.g., cash, bank deposit, or liquid assets) and regular flow of money (e.g., remittance, pension, and sale labor) (Islam et al, 2013). The participants have been involved in different organizations to get loans and technical assistance to manage the Date palm-based traditional agroforestry program, and the study observed that farmers get loan facilities and micro-credit with the easy condition. The total tree and crop outputs are the strong financial assets of the farmers and farmers can invest these assets in their human, physical and other assets as well. The study found that the proper management of the agroforestry 
systems would strongly build farmers' financial capital (Table 2).

The study also assesses the associated problems of the Date palm-based agroforestry systems that the farmers faced in the community. Most of the farmers (more than $90 \%$ ) mentioned that lack of updated information and assistance from the government officials (e.g., agriculture officers) were the main problems in their community. One of the important problems mentioned by the farmers was the marketing systems, lack of alternative market facilities and intermediary's intervention would hinder the farmers' income from selling their agroforestry products. Besides, these problems, the rural farmers have faced other minor problems like the unavailability of fertilizers and pesticides at the village levels. The study summarized that these associated problems have hindered the profitability of the systems and affecting their livelihood.

\section{CONCLUSION}

As a tree-crop-based production system, traditional Date palm agroforestry has numerous benefits that can contribute to rural farmers in light of the household income generation and livelihood improvements. The results of the study summarized that the Date palm agroforestry has to augment farmers' total household income in maximizing the benefit-cost ratio of the farm. Farmers received continuous income generation throughout the year the Date palm outputs also act as a backup for farmers in case of crop failure due to adverse climatic conditions. The study also concluded that the impact of the Date palm agroforestry has strongly improved the financial, physical and natural capital development of the rural farmers, however, the social and human capital development was not satisfactory. More emphasis needs to be placed on how traditional agroforestry could improve the farmers' human and social capital in the community. In addition, the rural farmers also faced some constraint which would hamper the productivity and outcomes of the traditional agroforestry system. There is now a current need to build on the existing social and human capital development of the farmers by providing them training on scientific agroforestry production and improve their relationship with agriculture officials in order to promote a more effective agroforestry system in the Jashore region of Bangladesh. Finally, the study can argue that the traditional agroforestry could be a more sustainable landuse system if the government and related stakeholders would provide their mutual support to the rural farmers and dissolve their production problem in a sustainable way.

\section{REFERENCES}

[1] Abedin, M. Z and Quddus, M. A. (1990). Household fuel situation, homegarden and Agroforestry practice at six agro-ecological different locations of Bangladesh. In: Homestead plantation and agroforestry in Bangladesh; Abedin MZ., Lai CK, Ali MO. (eds.). Proceedings of a National Workshop held in BARI, Gazipur, Bangladesh. pp.19-53.

[2] Abedin, Z., Akhter, S., Haque, F., Alam, A., Washington, D., Uicken, M. K. G., Sastry, C. B and Adams, N. R. (1997). Uses of multipurpose trees of the small farms of the low rainfall Ganges floodplain soils of Bangladesh. Proceedings of the Intl. Workshop, Nov. 2-5, 1987, Pattaya, Thailand.

[3] Avelino, J., Hoopen, G. M and DeClerck, F. (2011). Ecological mechanisms for pest and disease control in coffee and cacao agroecosystems of the neotropics. In: Ecosystem Services from Agriculture and Agroforestry: Measurement and Payment; Rapidel B, Le Coq JF, Beer J. (eds.). Earthscan Publications, London, pp. 91-118.

[4] BBS (2013). Bangladesh Bureau of Statistics (BBS). District Statistics, Jashore. pp.16.

[5] Branca, G., Mccarthy, N., Lipper, L. and Jolejole, M. C. (2011). Climate Smart Agriculture: A Synthesis of Empirical Evidence of Food Security and Mitigation Benefits for Improved Cropland Management. FAO, Rome, Italy. pp. 1-42.

[6] Carney, D. (1998). Sustainable Rural Livelihoods; What Contribution Can We Make? Department for International Development, London.

[7] Chowdhury, M. S. H., Halim, M. A., Muhammed. N., Haque, F. and Koike, M. (2008). Traditional utilization of wild date palm (Phoenix sylvestris) in rural Bangladesh: an approach to sustainable biodiversity management. Journal of Forestry Research, 19: 245-251.

[8] Dalibard, C. (2007). The potential of tapping palm trees for animal production. Available on: http://www.fao.org/AG/AGAINFO/resources/documents/fr $\mathrm{g} /$ conf96htm/dalibard.htm (accessed on 22 January 2021).

[9] Das, N. (2009). Can Joint Forest Management Programme Sustain Rural Life: A Livelihood Analysis from Community-based Forest Management Groups. MPRA paper No. 15305.

[10] Dersham, L. and Gzirishvili, D. (1998). Informal social support networks and household vulnerability: empirical findings from Georgia. World Development, 26: 18271838.

[11] DFID (2001). Sustainable livelihood guidance sheets: comparing development approaches. London: Department for International Development.

[12] Hajong, P., Mondal, S., Sikder, B., Paul, S. K. and Saha, D. (2016). Existing value chain assessment of date palm is selected areas of greater Jessore districts. Journal of Sylhet Agricultural University, 3(1): 53-58.

[13] Hussein, K. and Nelson, J. (1998). Sustainable Livelihood and Livelihood Diversification, IDS Working Paper, No. 69. Brighton, Institute of Development Studies. 
[14] Islam, K. K. (2019). Participatory agroforestry for disadvantaged community development: Evidence from Madhupur Sal forests, Bangladesh. Journal of Agroforestry and Environment,13 (1\&2): 7-12.

[15] Islam, K. K. and Sato, N. (2012a). Participatory forestry in Bangladesh: has it helped to increase the livelihoods of Sal forests-dependent people? Southern Forests: a Journal of Forest Science, 74(2): 89-101.

[16] Islam, K. K. and Sato, N. (2013). Protected Sal forests and livelihoods of ethnic minority: Experience from Bangladesh. Journal of Sustainable Forestry, 32(4): 412436.

[17] Islam,K. K., Hoogastra, M., Ullah, M. O. and Sato, N. (2012b). Economic contribution of participatory agroforestry program to poverty alleviation: a case from Sal forests, Bangladesh. Journal of Forestry Research, 23(2): 323-332.

[18] Islam, K. K.,Rahman, G. M., Fujiwara, T. and Sato, N. (2013). People's participation in forest conservation and livelihoods improvements: Experience from a forestry project in Bangladesh. International Journal of Biodiversity Science and Ecosystems Service Management, 9(1): 30-43.

[19] Miah, M. G., Ahmed, F. U., Ahmed, M. M., Alam, M. N., Choudhury, N. H and Hamid, M. A. (2002). Agroforestry in Bangladesh: Potential and opportunities. Paper presented in South Asia Regional Agroforestry Consultation Workshop held on 23-25 November, 2002 at New Delhi. India.

[20] Moser, C. (1998). The asset vulnerability framework: Reassessing urban poverty reduction strategies. World Development, 26: 1-19.

[21] Nair, P. K. R. and Latt, C. R. (1997). Directions in tropical agroforestry research. Agroforestry Systems, 38: 1-249.

[22] Nair, V. D. and Graetz, D. A. (2004). Agroforestry as an approach to minimizing nutrient loss from heavily fertilized soils: the Florida experience. Agroforestry Systems, 61: 269-279.

[23] Shahbaz, B. (2009). Dilemmas in participatory forest management in northwest Pakistan: A livelihoods perspective. Human Geography Series 25: 15-16.

[24] Sobel, J. (2002). Can We Trust Social Capital? Journal of Economic Literature, 40(1): 139-154.

[25] Warner, K. (2003). Moving forward: Development pathways for sustainable livelihoods through forestry. In: Defining the way forward: Sustainable livelihoods and sustainable forest management through participatory forestry,Iddi S, Sarrazin K, Reeb D (eds.). Second International workshop on participatory forestry in Africa, United Republic of Tanzania.

[26] World Bank, (2002). Impact on Migration on Economic and Social Development: A review of evidence and emerging issue. Available on: https://openknowledge.worldbank.org/handle/10986/3328 (accessed on 15 January 2021). 